\title{
DZIATKI MILE ELŻBIETY I STANISŁAWA KRUSZYŃSKICH
}

W zbiorach Zakładu Narodowego im. Ossolińskich we Wrocławiu znajduje się sylwa przypisywana od lat niejakiemu Hołodyńskiemu z Falkowy ${ }^{1}$. Jednakże lektura tekstów zamieszczonych w sylwie nie wskazuje, aby autorem był ktoś o nazwisku Hołodyński. Analiza treści sylwy pokazuje, że prawdopodobnie napisał ją Stanisław Kazimierz Kruszyński zamieszkały najpierw w Fałkowicach, następnie w Łąkcie Dolnej w pobliżu Trzciany. Wskazuje na to cały szereg przesłanek. Po pierwsze, w sylwie pojawia się Elżbieta Kruszyńska, żona Stanisława, jako autorka wiersza związanego ze śmiercią dzieci. Elżbieta była z domu Hołodyńska, jej ojciec Franciszek i stryj Ignacy, proboszcz w Gdowie w latach I7II-I7I4, występują na łamach omawianej sylwy, stąd może błędne ustalenie jej autora. Kolejną przesłanką pozwalającą na ustalenie autorstwa sylwy jest zachowany testament Stanisława Kazimierza Kruszyńskiego $^{2}$. Wymienione $\mathrm{w}$ testamencie dzieci Kruszyńskiego dokładnie odpowiadają tym wspomnianym w sylwie.

Podobnie błędnie została odczytana nazwa miejscowości. Kruszyńscy mieszkali w Fałkowicach, nie w Falkowej, w „dworze fałkowskim za rzeką Rabą”, co odpowiada położeniu Fałkowic, leżących w gminie Gdów. W związku z tym, za autora sylwy uznać należy Stanisława Kazimierza Kruszyńskiego herbu Pomian.

Wśród wielu różnorodnych tekstów wpisanych do omawianej sylwy zamieszczone są zapisy dotyczące dzieci. Są to: „Konnotacyja dziatek, k[tó]re mi Pan Bóg dał i kiedy się porodziły, pod jakim planetą i znamionem dnia i roku”, następnie „Informacyja synom moim, jeżeli ich P[an] Bóg chować będzie: Stanisławowi, Michałowi i Sebastianowi, i Józysiowi” oraz „Konnotacyja ksiąg, które potrzebne są do czytania dla iluminacyjej każdemu człowiekowi”. Dwa ostatnie teksty napisane w roku I724 stanowiące razem instrukcję wraz ze spisem lektur zostały wydane przez Bogdana Roka ${ }^{4}$, a ostatnio w tomie instruk-

\footnotetext{
* Prof. zw. dr hab. Dorota Żołądź-Strzelczyk, Uniwersytet im. Adama Mickiewicza w Poznaniu, Zakład Historii Wychowania WSE. E-mail: dorotast@amu.edu.pl.

1 Sylwa Hołodyńskiego z Falkowy w Sądeckim (między rokiem 1690 a 1725, Zakład Narodowy im. Ossolińskich, sygn. $2027 \mathrm{I}$.

2 Por. Testament z addytamentem Stanisława Kazimierza Kruszyńskiego cześnika liwskiego, w: Testamenty szlachty krakowskiej XVII-XVIII w., oprac. A. Falniowska-Gradowska, Kraków 1997, s. 64-70.

3 Konnotacyja dziatek, k[tó]re mi Pan Bóg dał i kiedy się porodziły, pod jakim planetą i znamionem dnia i roku, w: Sylwa Hołodyńskiego z Falkowy w Sądeckim (między rokiem 1690 a 1725), Zakład Narodowy im. Ossolińskich, sygn. 2027 I, k. 102-103v.

4 B. Rok, Szlachecka instrukcja wychowawcza i biblioteczka domowa z 1 połowy XVIII w., w: Studia i materiaty z dziejów nowożytnych, red. K. Matwijowski, S. Ochmann-Staniszewska, Wrocław 1995, s. 223-232.
} 
cji rodzicielskich pochodzących z wieku XVIII przez Małgorzatę E. Kowalczyk i Dorotę Żołądź-Strzelczyk 5 . W tej samej sylwie znajduje się także wspomniany wiersz napisany przez Elżbietę Kruszyńską związany ze śmiercią dwójki dzieci - Józefa i Marii. Ponadto Kruszyński pozostawił po sobie testament spisany w roku I $725 \mathrm{z}$ dodatkiem pochodzącym z I730 roku, w którym również znajdują się zalecenia dotyczące jego dzieci. Tak więc istnieje kilka źródeł mówiących o potomstwie małżonków Kruszyńskich.

Stanisław Kazimierz Kruszyński (zm. I730), jak sam napisał w testamencie, pochodził z rodziny wywodzącej się z Kruszenic. Była to prawdopodobnie rodzina herbu Pomian. W herbarzu Bonieckiego jest zapis o Stanisławie Kazimierzu Kruszyńskim herbu Pomian, z rodziny wywodzącej się z Kruszenic w ziemi płockiej, cześniku liwskim, towarzyszu pancernym. Według tego herbarza otrzymał on w dożywocie od Augusta II w roku I699 miejscowość Buchny, w I7I3 natomiast pozwolenie na odstąpienie wójtostwa w Smotryczu Lubomirskim 6 .

Urodzony, jak można przypuszczać, około I670-I675 roku, był dwukrotnie żonaty. Z pierwszą, nieznaną z imienia, żoną „mieszkając lat kilkanaście nie dał nam był Pan Bóg potomstwa"?. Z drugą, Elżbietą z Hołodyńskich, córką Franciszka z Gdowa, miał czterech synów: Stanisława, Michała, Sebastiana i Józefa oraz dwie córki: Wiktorię i Mariannę. Rodzina mieszkała najpierw w Fałkowicach, a następnie w Łąkcie Dolnej w Małopolsce.

Kruszyński poślubił Elżbietę z Hołodyńskich zapewne około roku I7I9, we wrześniu kolejnego roku ,we dworze fałkowskim za rzeką Rabą” przyszło na świat ich pierwsze dziecko, syn, któremu ,dano te imiona Stanisław i Michał, bo w piątek było Przeniesienia św. Stanisława, a w niedzielę św. Michała”. W sobotę go „ochrzczono we dworze fałkowskim, to jest dnia 287 bris krzcił go Jm. Ksiądz Ignacy Hołodyński pleban gdowski”. Rodzicami chrzestnymi byli ojciec Elżbiety, Franciszek Hołodyński, oraz Anna Mierowa, matka generała Wilhelma Miera.

Rok później, już w nowym miejscu w Łąkcie Dolnej, w „łąkieckim dworze”, urodził się kolejny syn, Michał Franciszek, który został ochrzczony w domu zaraz po narodzeniu przez księdza Strzeszewskiego proboszcza trzciańskiego „prywatnie dla słabości zdrowia [...] przez ungowania”, a w jakiś czas później „był chrzczony krzyżmem z innymi ceremoniami w Krakowie u Panny Maryjej przez J. księdza Franciszka Starowicza wikarego". Chrzestnymi byli książę Teodor Lubomirski i Anna z Lubomirskich Małachowska, druga żona Stanisława, wojewody poznańskiego ${ }^{8}$.

W roku I722 w grudniu ,urodziła mi się córka, której dał imię Jm. ksiądz Jan z klasztoru trzciańskiego, Wiktoria”. Zaraz po przyjściu na świat została ochrzczona „prywatnie przez pomazania krzyżma św.”, po czym, po pewnym czasie, 28 lutego I723 roku, ponownie „krzyżmem chrzczona z ceremoniami kościelnemi z tegoż wyżej klasztoru pomienionego trzciańskiego przez Jmć księdza Tomasza Strzeszewskiego proboszcza”. Trzymali ją do chrztu małżonkowie Antoni i Teresa Dębińscy. Antoni to stolnik i łowczy krakowski, a Teresa z Lipskich, córka Jana, była jego drugą żoną. Dziewczynka nie cieszyła się dobrym

\footnotetext{
5 S.K. Kruszyński, Informacja synom moim, w: Przestrogi i nauki dla dzieci. Instrukcje rodzicielskie (XVIII w.), wstępem i objaśnieniami opatrzyły M.E. Kowalczyk i D. Żołądź-Strzelczyk, Wrocław 2017, s. 29-43.

6 Herbarz polski, cz. I: Wiadomości historyczno-genealogiczne o rodach szlacheckich, ułożył i wydał A. Boniecki, t. XII, Warszawa 1908, s. 368.

7 Testament..., s. 65.

8 Konnotacyja dziatek ..., k. 102v.
} 
zdrowiem, ojciec w testamencie pisał o niej „o Wiktoryi proszę mieć pamięć jako o kalice, jeżeli ich Pan Bóg chować będzie". Nie wiadomo, czy urodziła się kaleką, czy też jej kalectwo było skutkiem choroby.

W roku I724, w dzień „św. Fabiana i Sebastiana”, czyli 20 stycznia urodził się „syn, którego chrzcił prywatnie przez krzyżma Jmć ksiądz Kukliński ze Trzciany kaznodzieja". Chłopiec dostał imiona Sebastian i Franciszek, a rodzicami chrzestnymi byli Stefan Wielogłowski, cześnik rawski, i skarbnikowa dobrzyńska Anna Grzembska, żona Antoniego ${ }^{\text {I0 }}$.

W sierpniu I725 roku, „W sobotę o godzinie siódemej z rana urodził mi się syn, którego prywatnie chrzcił tegoż dnia przez ungowania i innych ceremonij kościelnych Jm. ksiądz Franciszek kaznodzieja trzciański, a że w wigilię św. Jacka, którego było w niedzielę, urodził się dano mu imię pierwsze Józef, a drugie Jacek". Dwa miesiące później został ponownie ochrzczony w kościele w Trzcianie, trzymali go do chrztu Władysław z Brzezia Russocki i Jadwiga Rossowa ${ }^{\text {II }}$. Ostatnie dziecko, córeczka Maria, urodziła się w grudniu 1726 roku.

Analizując zapisy dotyczące narodzin kolejnych dzieci w rodzinie Kruszyńskich, należy zwrócić uwagę na kilka zagadnień. Po pierwsze, na zwyczaje związane z chrztem. Dzieci w tej rodzinie były chrzczone dwa razy. Pierwszy raz ,prywatnie” w domu zaraz po przyjściu na świat. Być może wynikało to z kondycji fizycznej, w jakiej się rodziły. W jednym przypadku zapisano „dla słabości zdrowia”. Ten pierwszy chrzest był skromny, szybki, bez przewidzianego dla uroczystości ceremoniału, „,przez ungowania”, „bez krzyżma”. Po pewnym czasie, niekiedy, jak to było w przypadku najmłodszego syna Józefa, nawet po dwóch miesiącach, odbywał się ponowny chrzest, w kościele, $\mathrm{z}$ ceremoniałem, $\mathrm{z}$ rodzicami chrzestnymi. Ten drugi chrzest miał miejsce najczęściej w kościele w Trzcianie, ale pierwsze dziecko chrzczone było w Krakowie w kościele Mariackim.

Wybór rodziców chrzestnych warunkowało urodzenie rodziców naturalnych, ich pozycja w społeczeństwie. Chrzestni powinni wspierać dziecko i jego rodzinę począwszy od chrztu. Dzieci Kruszyńskich trzymali najczęściej przedstawiciele okolicznej szlachty. Wyjątkowo pierworodnego syna trzymał dziadek, Franciszek Hołodyński. Najbardziej dostojnych rodziców miał drugi syn, Michał Franciszek. Byli to książę Teodor Lubomirski i Anna z Lubomirskich Małachowska, wojewodzina poznańska.

Kolejna sprawa to wybór imienia dla dziecka ${ }^{\mathrm{I}}$. Częstym zwyczajem było „przynoszenie” sobie imienia, tzn. nadawano imię patrona dnia przyjścia na świat, czasami z kalendarza wybierano imię świętego, który patronował najbliższym dniom. Niekiedy decydowała rodzinna tradycja i imię dostawało się po dziadku, babce lub innym krewnym. Wreszcie nadawano imiona chrzestnych, ewentualnie osób znaczących, władców. W XVIII wieku obserwuje się także nadawanie imion postaci literackich z modnych i chętnie czytywanych dzieł. W przypadku Kruszyńskich zdecydowanie dominowało wybieranie imienia ,przyniesionego” przez dziecko, nadawano imiona świętych patronujących dniom zbliżonym do dnia jego przyjścia na świat. Chociaż najprawdopodobniej uwzględniano również imiona rodzinne, tak było w przypadku pierworodnego syna, który imię Stanisław otrzymał nie tylko w związku $\mathrm{z}$ dniem narodzin, ale imię to nosił także jego ojciec. Dwóch synów na drugie imię dostało

\footnotetext{
Testament..., s. 67.

10 Konnotacyja dziatek ..., k. 103v.

11 Tamże, k. 103v.

12 D. Żołądź-Strzelczyk, Dziecko w dawnej Polsce, Poznań 2002, s. 78-82.
} 
Franciszek, prawdopodobnie po dziadku ze strony matki. Niestety brak dokładniejszych informacji na temat uwarunkowań rodzinnych w zakresie nadawania imienia. Niewątpliwie jednak, o czym informuje cytowane źródło, brano pod uwagę datę narodzin.

Kruszyńscy mieli więc sześcioro dzieci: Stasia, Michasia, Wiktorię, Sobosia, Jozusia i Marysię. Niestety dwójka najmłodszych - Jozuś i Marysia - zmarła w maju I727 roku. Ponieważ zmarli dzień po dniu - „Jozuś [...] umarł we wtorek rano jak świtało die 20 maja I727 [...] Marysia [...] umarła dnia 2I maja w środę", można podejrzewać, że zachorowali i właśnie to było przyczyną ich śmierci, być może chorowały również starsze dzieci, ale te najmłodsze, najsłabsze nie wyszły z choroby.

Temu smutnemu wydarzeniu ich matka Elżbieta poświęciła wiersz „swoim dziatkom kochanym dwojgu, Józefowi, który 7 ćwierci roku miał i Maryjannie, która miała niedziel 22 nagrobek napisała"’3.

Dniu nieszczęśliwy, w którego godzinę

Śmierć mi żałosną przyniosła nowinę.

Gdy dziatek dwoje kochanych zabrała

A jam tu matka smutna pozostała.

Wiersz zawiera rozważania nad ludzką śmiertelnością -,„nie zgadniemy czy nasze momenta, czy zakończymy cośmy rozpoczęli”, matka rozpacza, że „najkochańszych dzieci daje parę" i prosi Boga o łaskę cierpliwości. Rozumie, że dzieci były darem Boga, który wziął je ,,jak swoje do siebie”. Ale widać żal, że ,śmierć niedyskretna jako się zakrząta nie tylko jedno, razem dwoje sprząta". Jozuś i Maryjanna pochowani zostali w Trzcianie w tamtejszym kościele, tam również spoczęli ich rodzice. Ojciec wyraźnie napisał w testamencie, żeby pochować go: ,jeżeli we wsi Łąkcie Dolnej umrę, aby przy kościele trzciańskim przed progiem drzwi wielkich kościelnych, na boku po prawej ręce do kościoła idąc"I4.

Mając świadomość własnej śmiertelności - „,znając się być śmiertelny i śmiertelności podlegającym”, mając słabe zdrowie - „będąc w zdrowiu słabym, na umyśle jednak zupełną zdrowość mając”, wreszcie chcąc zabezpieczyć dzieci, Kruszyński spisał kolejno kilka dokumentów. Najpierw w I724 roku instrukcję dla synów dotyczącą ich edukacji, następnie w I725 testament i kilka lat później, już po śmierci drugiej żony, w I730 roku dodatek do testamentu. Zmarł w tymże roku, a o tym, co działo się z jego dziećmi, pozostały tylko skąpe informacje.

Instrukcja ojcowska skierowana była pierwotnie do trzech synów: Stanisława, Michała i Sebastiana, ale kiedy urodził się Józef, Kruszyński dopisał jego imię. Przede wszystkim zalecał synom „P[ana] Boga się bać i według przykazania Jego ś[więtego] żyć w katolickiej rzymskiej wierze i w niej umierać!'’5.

Chłopcy powinni ,od lat 7, a najdalej I2, do nauk się sposobić jako najlepiej, bo kto ma naukę i umie jej zażyć, jakoby największy miał skarb"ı. Wnosić można stąd, że Kruszyński w młodości otrzymał jakieś wykształcenie, rozumiał jego znaczenie i chciał, aby synowie

\footnotetext{
13 Sylwa Hołodyńskiego z Falkowy... 190v-191; wspomina ten wiersz i przytacza jego fragment S. Roszak, $A r$ chiwa sarmackiej pamięci. Funkcje i znaczenie rękopiśmiennych ksiag silva rerum w kulturze Rzeczypospolitej XVIII wieku, Torun 2004, s. 217.

14 Testament..., s. 64.

15 S.K. Kruszyński, Infromacyja synom moim..., s. 33.

16 Tamże.
} 
kształcili się, co miało im pomóc w życiu. Planował, aby po nauce w „m[n]iejszych” szkołach „osobliwie w gramatyce jako najlepiej fundament konstrukcyjej założyć, a potym do dalszych agredi! Skończywszy szkoły retorykę, choćby 3-letnią, to in publicis może traktować lekcyje”" ${ }^{\prime \prime}$. W testamencie zaś zalecał, aby synów do „szkół podolinieckich do oo. pijarów „Scholarum Piarum” dać, jak im po ośm albo po dziewięć lat będzie”. Podobnie w dodatku, napisanym w I730 roku pisał: „,dzieci w maju [...] odwieźć do Podoleńca do konwiktu i zaraz zgodziwszy się z tamtejszym rektorem co do wszystkich trzech - nie żył już Józef - należeć będzie, dać pieniądze na ćwierć roku, albo na pół roka" ${ }^{19}$. Kruszyński nie cenił zdaje się zbytnio jezuitów, zalecał wysłanie synów do pijarów, bo pisał „,pijarowie ich profesyja uczyć, szkoły, i przysięgają na to, a jezuici nie. Dlatego też lepiej i szczerzej pijarowie uczą" ${ }^{20}$. Kolegium pijarów w Podolińcu ufundował wojewoda krakowski Stanisław Lubomirski w I642 roku, zalecając „,by zgodnie ze swoim powołaniem ćwiczyli młodzież w chrześcijańskiej pobożności i w naukach” oraz aby „wiarę i religię katolicką szerzyli przez głoszenie kazań i katechizację". Skierowanie chłopców do Podolińca mogło również wynikać ze związków łączących ich ojca z Lubomirskimi. Terenem aktywności Kruszyńskich były okolice Wiśnicza, rodowej od pokoleń siedziby Lubomirskich. Łąktę Dolną, gdzie mieszkali, dzieli od Wiśnicza w linii prostej niecałe Io kilometrów. Przedstawiciele rodziny Lubomirskich, jak już wspomniano, trzymali do chrztu najstarszego syna cześnika liwskiego. Z innym Lubomirskim, Jerzym Aleksandrem, Kruszyński miał jakieś sprawy majątkowe ${ }^{22}$.

Po naukach w Podolińcu synowie „do Krakowa na publiczne lekcyje w wielkim Kolegium mogliby z rok chodzić albo pół roku, a dopiero do prawa, do kancelaryi akomodować ich, które najpotrzebniejsze każdemu s[z]lachcicowi, aby byli ze dwie lecie"²3. Naukę w kancelarii zalecał także w instrukcji: ,do kancelaryjej i być w niej koniecznie lat 3, aby zrozumieć co to jest prawo, które jest bardzo potrzebne każdemu s[z]lachcicowi, co nie tylko sobie dogodzi, ale i komu poradzi, a kiedy będzie symplak, to musi jeździć, radzić się i płacić niewinnie" "24. W tym czasie, aby nie zeszli na złą drogę, powinni być oddani „W dobre ręce komu słusznemu i aby wikt u niego mieli i on ich informował i doglądał, aby się nie bikowali’’’s.

Kolejnym etapem po nauce w kancelarii konieczna byłaby jeszcze praktyka w trybunale, tam „choć rok I agentować, bo kiedy się przytrafi być deputatem na Trybunał już in arte iuridica doskonały będzie i do sądu każdego" ${ }^{26}$. Następnie młody człowiek, według Kruszyńskiego, miał kilka możliwości wyboru drogi życiowej: służbę dworską, wojskową, gospodarowanie lub służbę w Kościele.

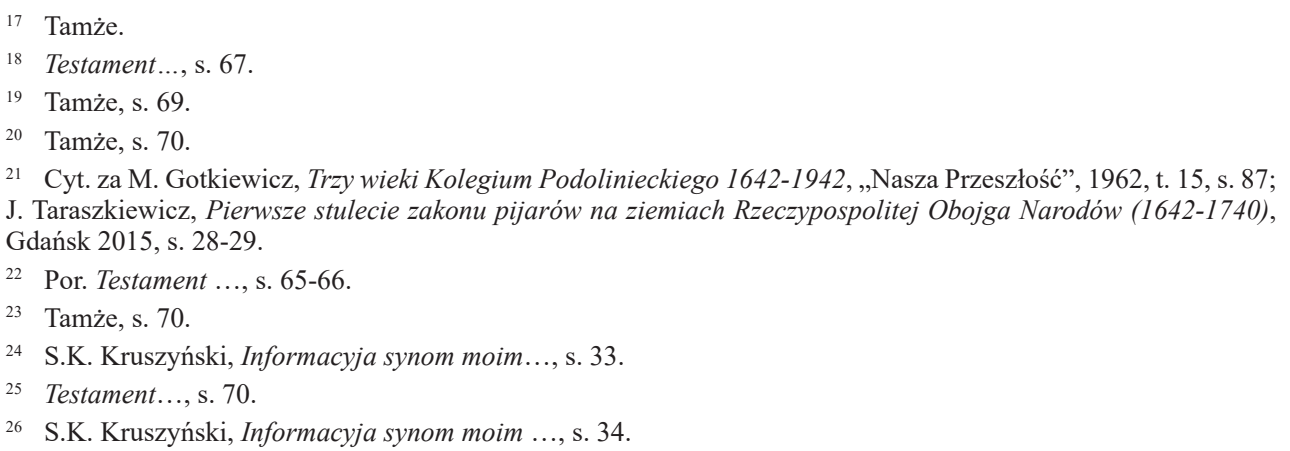


Pierwsza możliwość - służba na dworze - w tym przypadku najlepiej dostać się „,do tych ministrów, którzy zawsze blisko są króla. Jako to do marszałka koronnego, kanclerza, podskarbiego", przy nich uzyskać jakiś urząd i ,już bieda nie dokuczy temu, ile kto się skarbu chwyci" 27. Służba wojskowa też związana była z koniecznością uzyskania poparcia wpływowych ludzi, tak więc młody człowiek powinien starać się „koniecznie do hetmanów i tych regimentarzów, co są pier[w]si w komendach, a tak znajomość, respekt i dalsza promocyja być może przy aplikacyjej, ale do tych pomniejszych i nikczemnych nie trzeba się cisnąć, bo mało mogą dopomóc i sami sobie"28. Kolejna droga to gospodarowanie - ,jeżeli do gospodarstwa, to jest sprawiedliwy żywot, bo gospodarz, co mu dał P[an] Bóg z roli pożytku, tym się kontentując, jest najs[z]częśliwszy i w zbawieniu bezpieczen"29. I wreszcie młody człowiek może wybrać karierę duchownego. „Piękna rzecz Bogu oddać się na służbę wieczną i żyć nieodmiennie", ale jest to służba bardzo odpowiedzialna, wiele od człowieka wymagająca i nie każdy jest jej godny. I dlatego Kruszyński radzi: we „wszelkim stanie Boga chwalić może i zbawienie otrzymać, żyjąc według pr[z]ykazania boskiego, przecież do tego się sposobić, do którego chęć wiedzie"’30.

W instrukcji pojawiają się napomnienia dotyczące towarzystwa i zachowania młodych. Kruszyński uważa, że chłopcy powinni ,kompanijej lekkiej, swywolnej i od ludzi wszet[e]cznych uciekać, i nie przestaw[a]ć z nimi, ale z ludźmi statecznemi, którzy i w młodym wieku znajdują się, przestawać. Tańców na miejscach pospolitych i konwersacyjej chronić się lubieżnej. A w jako najlepszej trzeźwości żywot prowadzić, bo gdzie jest trzeźwość, tam wszelka moderacyja, gdzie pijaństwo panuje, tam wszytko złe panuje, bo w głowie jako w browarze, do tego i szwank na zdrowiu bywa tym, co gorące trunki piją, jako to gorzałka osobliwie, skąd ono aksjoma urosło u mądrych, że gula plures occidit, quam gladius, osobliwie w naszej Polscze, bo w cudzych krainach moderatius żyją i piją, dlatego też capaciosa u nich subiecta znajdują się nad polskie"3i. Ojciec przestrzegał synów przed złym towarzystwem, a przede wszystkim przed pijaństwem, które powoduje, że młodzi ludzie tracą zdrowie, pieniądze, nabywają złych obyczajów.

W testamencie zwracał się do dzieci ,dziatki moje kochane, jak do doskonałego przyjdziecie rozumu, o duszy mojej nie zapominać, a matkę szanować. Przykazuję pod błogosławieństwem ojcowskim, które wam daję takie, aby was Bóg we wszystkim i na wszystkiem gdziekolwiek będziecie i cokolwiek mieć będziecie w życiu waszym błogosławił. O przyjaźń ludzką zawsze się starać, serce swe uniżone mieć zawsze niewyniosłe, ani pyszne, choćby i największa kredensował fortuna, bo to są rzeczy prędko odmieniające i momentalne. Człeka by najlichszego lekce sobie nie ważyć, a starych szanować i uczciwość im wyrządzać, macie tam dostateczna informacyją w manuskryptach moich”32. Wyraźnie kieruje dzieci do swoich zapisek w sylwie, w których znajdowała się wspomniana instrukcja.

Biorąc pod uwagę zawarte w instrukcji zalecenia, a także spis ksiąg, będących być może częścią instrukcji, można przypuszczać, że Kruszyński był człowiekiem wykształconym. Spis

\footnotetext{
Tamże, s. 36.

28 Tamże.

29 Tamże.

30 Tamże.

31 Tamże, s. 34.

32 Testament..., s. 67.
} 
ksiąg mógł być wprawdzie spisem posiadanych przez Kruszyńskiego pozycji, ale przeciwko temu przemawiają błędy, jakie się w nim znalazły. Wydaje się, że gdyby wymienione księgi posiadał, nie napisałby na przykład: „Książka authore Zalaszowski in folio, czyli w Krakowie, czyli w Poznaniu drukowana, bardzo piękna, ad formam atlasa, pisze i o niebach, i o sferach, i innych"33. Zalaszowski był autorem dzieł o tematyce prawniczej, a więc odległej od tej, którą sygnalizuje zapis Kruszyńskiego. Biorąc pod uwagę treść instrukcji i spis książek oraz to, co podał w tytule spisu, gdzie wspomina o księgach, które „potrzebne są do czytania dla iluminacyjej każdemu człowiekowi”, sądzić należy, że Kruszyński znał te księgi, tym samym potwierdza się założenie, że musiał być osobą wykształconą i zdawał sobie sprawę ze znaczenia odpowiedniego wykształcenia w życiu i karierze.

Kruszyński, sam wykształcony, chciał, aby jego synowie również otrzymali odpowiednie wykształcenie. W dodatku do testamentu spisanym po śmierci żony, niedługo przed własną śmiercią, której pewnie się spodziewał, jako że zdrowie mu chyba nie dopisywało, zamieścił dokładne wskazówki w tym zakresie. Zalecał, aby trzech chłopców - Józef jak już wspomniano zmarł w tym czasie - „w maju, to jest na Zielone Świątki, odwieźć do Podoleńca do konwiktu”34. Pozostawił także wskazówki dotyczące wyposażenia chłopców: „sukienek po dwie parze kazać im porobić. Jedne falandyszowe na powszedni dzień, a drugie od święta [z] francuskiego sukna. Jedne kitajowe żupany, a drugie choć falendyszowe, bo to mocniej będzie, a oni drą prędko suknie. Chust każdemu dać po par kilka, aby było na przewłoki porządnie i wszystkie koszule jednakowe, co kożdy może wdziać. Koszule, czapek i botów tych nad zamian potrzeba. Są skrzynki dwie, co dla nich za suknie będą i chusty, jako i książki chować" 35 .

Starał się również zabezpieczyć ich po swojej śmierci pod względem materialnym i życiowym, w tym zakresie dał wskazówki bratu Andrzejowi, gospodarującemu w Pogwizdowie. Miał on, razem z żoną, zamieszkać w Łąkcie, „wieś Łąktą wziąć w swoję dyspozycyją i rządzić się jako najlepiej sprowadziwszy się"36 i tam doglądać majątku i dzieci. Wszystkie swoje suknie przekazywał bratu, „tylko rząd mój złocisty i ten drugi, proszę dzieciom moim dotrzymać”. Dla dzieci należało też „dochować” ojcowskie ,,szable obiedwie oprawne i sahajdak złocisty blachmalowy i szabla z perska i dwie proste i Multan, i wszytkę strzelbę z hakownicami dwiema”. Wskazywał co sprzedać i w ten sposób „zgromadzić pieniądze do kupy dla dzieci"s3.

Jak wspomniano, o późniejszych losach dzieci Stanisława i Elżbiety Kruszyńskich nie ma zbyt wielu informacji. Z szóstki pociech dwójka zmarła jeszcze za życia rodziców, kaleka Wiktoria pewnie dożyła swych dni w Łąkcie u boku ciotki. Chłopcy w chwili śmierci ojca byli jeszcze mali, najstarszy miał zaledwie Io, najmłodszy 6 lat. Zapewne posłani zostali do szkół, zgodnie z wolą ojcowską. Boniecki wspomina dwóch z nich: Stanisława i Michała. Michał wybrał karierę wojskową, był kapitanem wojsk koronnych, tytułowany skarbnikiem gostyńskim, ożenił się z Katarzyną Borowską ${ }^{38}$.

\footnotetext{
33 S.K. Kruszyński, Konnotacyja ksią..., s. 42.

34 Addytament..., s. 69.

35 Tamże, s. 70.

36 Tamże, s. 68.

37 Tamże, s. 69.

38 Herbarz polski..., s. 368.
} 
Jego zapewne synem był Stanisław Kostka z Kruszenic Pomian Kruszyński. W semestrze letnim I762 roku wpisał się do metryki krakowskiej39, w I768 został bakałarzem, a trzy lata później, w I77I, magistrem filozofii ${ }^{40}$. Następnie „w przesławnej Akademii Krakowskiej nauk wyzwolonych filozofii doktor, matematyki profesor, szkół kazimierskich senior”. Pozostawił on po sobie kilka mów i kazań okolicznościowych, kalendarzy na lata I774-I777 ${ }^{4 \mathrm{I}}$. Jedno z kazań „,na uroczyste pochowanie kości w kościele pogwizdowskim miane” z I775 roku potwierdza jego powiązania z przedstawioną rodziną Kruszyńskich herbu Pomian. W Pogwizdowie mieszkał i gospodarował Andrzej Kruszyński, brat Stanisława Kazimierza.

Omówione w niniejszym artykule źródła pozwalają na odtworzenie fragmentów dziejów rodziny Kruszyńskich dotyczących dzieci Elżbiety i Stanisława mieszkających najpierw w Fałkowicach, a następnie w Łąkcie Dolnej, niedaleko Wiśnicza w Małopolsce. Rodzice wcześnie osierocili synów i córkę. Szczęśliwie dla dzieci ojciec powierzył opiekę nad nimi bratu i bratowej, którzy prawdopodobnie z tego obowiązku dobrze się wywiązali.

\section{Strzelczyk Dorota, Little ones of Elżbieta and Stanisław Kruszyńscy Summary}

The article uses source materials to present the situation of the family of Stanisław Kazimierz Kruszyński, a noble living with his relatives in Lower Łąkta in Lesser Poland. The sylwa stored in the collection of Ossolineum in Wroclaw, contains several messages about children. These are notes speaking of the birth of subsequent children, the place and circumstances of their baptism. We also have a poem written by a mother after the death of her youngest children. And above all same, recommendations for the education of sons to be found in the will and the supplement to it. They had to study at the Piarist college in Podoliniec and then practice at the office. These few preserved sources provide us with information about family life and attitudes towards children in the early $\mathrm{I} 8^{\text {th }}$ century.

[tł. Joanna Strzelczyk]

Keywords: childhood, upbringing and education, I $8^{\text {th }}$ Century, Kruszyński family

\section{BIBLIOGRAFIA}

Źródła

Album studiosorum Universitatis Cracoviensis, t. V, editionem curavit C. Lewicki adiutus a G. Zathey, Cracoviae-Wratislaviae 1956.

Konnotacyja dziatek, k[tó]re mi Pan Bóg dał i kiedy się porodziły, pod jakim planetą i znamionem dnia i roku, w: Sylwa Hołodyńskiego z Falkowy w Sądeckim (między rokiem I690 a I725), K. I02-IO3V.

\footnotetext{
39 Album studiosorum Universitatis Cracoviensis, t. V, editionem curavit C. Lewicki adiutus a G. Zathey, Cracoviae-Wratislaviae 1956, s. 140.

40 Statuta nec non liber promotionum Philosophorum Ordinis in Universitate Studiorum Jagellonica ab anno 1402 ad an. 1849, ed. J. Muczkowski, Cracoviae 1849, s. 423 i 425.

41 Por. K. Estreicher, Bibliografia polska, t. 20, Kraków 1905, s. 310-312.
} 
Kruszyński S.K., Informacja synom moim, w: Przestrogi i nauki dla dzieci. Instrukcje rodzicielskie (XVIII w.), wstępem i objaśnieniami opatrzyły M.E. Kowalczyk i D. Żołądź-Strzelczyk, Wrocław 20I7, s. 29-43.

Statuta nec non liber promotionum Philosophorum Ordinis in Universitate Studiorum Jagellonica ab anno I402 ad an. I849, ed. J. Muczkowski, Cracoviae I849.

Sylwa Hołodyńskiego z Falkowy w Sądeckim (między rokiem I690 a I725), Zakład Narodowy im. Ossolińskich, sygn. 2027 I.

Testament z addytamentem Stanisława Kazimierza Kruszyńskiego cześnika liwskiego, w: Testamenty szlachty krakowskiej XVII-XVIII w., oprac. A. Falniowska-Gradowska, Kraków I997, s. 64-70.

Opracowania

Estreicher K., Bibliografia polska, t. 20, Kraków 1905.

Gotkiewicz M., Trzy wieki Kolegium Podolinieckiego I642-1942, „Nasza Przeszłość”, 1962, t. I5, s. 83-II3.

Herbarz polski, cz. I: Wiadomości historyczno-genealogiczne o rodach szlacheckich, ułożył i wydał A. Boniecki, t. XII, Warszawa 1908.

Rok B., Szlachecka instrukcja wychowawcza i biblioteczka domowa z I polowy XVIII w., w: Studia i materiaty z dziejów nowożytnych, red. K. Matwijowski, S. Ochmann-Staniszewska, Wrocław 1995, s. 223-232.

Roszak S., Archiwa sarmackiej pamięci. Funkcje i znaczenie rękopiśmiennych ksiag silva rerum w kulturze Rzeczypospolitej XVIII wieku, Torun 2004.

Taraszkiewicz J., Pierwsze stulecie zakonu pijarów na ziemiach Rzeczypospolitej Obojga Narodów (I642-I740), Gdańsk 2015.

Żołądź-Strzelczyk D., Dziecko w dawnej Polsce, Poznań 2002. 